\title{
Households' Electrical Energy Conservation and Management: An Ecological Break-Through, or the Same Old Consumption-Growth Path?
}

\author{
Zbigniew Bohdanowicz $^{1,2} \mathbb{D}$, Beata Łopaciuk-Gonczaryk ${ }^{2, *} \mathbb{C}$, Jarosław Kowalski ${ }^{1}$ and Cezary Biele ${ }^{1}$ \\ 1 Laboratory of Interactive Technologies, National Information Processing Institute, 00-608 Warsaw, Poland; \\ zbigniew.bohdanowicz@opi.org.pl (Z.B.); jaroslaw.kowalski@opi.org.pl (J.K.); cezary.biele@opi.org.pl (C.B.) \\ 2 Faculty of Economic Sciences, University of Warsaw, 00-241 Warsaw, Poland \\ * Correspondence: bgonczaryk@wne.uw.edu.pl
}

Citation: Bohdanowicz, Z.; Łopaciuk -Gonczaryk, B.; Kowalski, J.; Biele, C. Households' Electrical Energy Conservation and Management: An Ecological Break-Through, or the Same Old Consumption-Growth Path? Energies 2021, 14, 6829. https://doi.org/10.3390/ en14206829

Academic Editor: David Borge-Diez

Received: 13 September 2021

Accepted: 13 October 2021

Published: 19 October 2021

Publisher's Note: MDPI stays neutral with regard to jurisdictional claims in published maps and institutional affiliations.

Copyright: (c) 2021 by the authors. Licensee MDPI, Basel, Switzerland. This article is an open access article distributed under the terms and conditions of the Creative Commons Attribution (CC BY) license (https:/ / creativecommons.org/licenses/by/ $4.0 /)$.

\begin{abstract}
We examine the motivations behind the electrical energy conservation and smart management at households to verify whether we are observing an ecological breakthrough, or a mere continuation of the well-trodden consumption-growth path. We conducted an online survey in France, Spain, Italy, and Denmark $(n=3200)$ on the subject of electricity use and generation. We utilized a generalized structural equation model to simultaneously test the direct reasons behind different energy-use behaviors and intentions, as well as their motivating factors. Measures to conserve electrical energy and install renewable energy equipment are not solely driven by ecological concerns; a crucial role is played by openness to new technologies, which correlates with high financial status. Saving electrical energy and new-tech eagerness go hand-in-hand with attachment to consumption and comfort. Social environment is relevant, as it allows users to converse about electricity saving with friends, and to observe their habits. Individuals may aim not to consume less energy, but to enhance their standards of living by economizing energy to fund other purchases, which limits the reduction in carbon footprint. Increasing the popularity of energy-saving solutions, therefore, might prove insufficient in the face of environmental threats and the challenges of transforming the energy market.
\end{abstract}

Keywords: attachment to consumption; energy usage flexibility; motivations; reducing greenhouse gas emissions; smart grid solutions; social networks

\section{Introduction}

The importance of energy efficiency rises with time. Progressively more attention is being paid to minimizing the energy consumption of buildings and electrical appliances, and in the fuel consumption of vehicles. The need to use energy more efficiently is caused by both the climate crisis, resulting from anthropogenic greenhouse gas (GHG) emissions [1] and by limited availability of traditional energy sources that can be obtained in a costeffective manner [2]. Both of these pressures will increase in the future. Despite efforts by the international community to reduce the scale of GHG emissions (Kyoto Protocol 1997; Paris Agreement 2015), global consumption of fossil fuels is increasing, and the risk of dangerous consequences of climate destabilization is growing [3]. Additionally, there is a threat that the availability of fossil fuels may begin to decline rapidly in the coming decades, due to the exponentially increasing cost of extraction of these fuels, further reducing the available time to transition the economy to new energy sources [4].

In this article, we deal with electrical energy because it is the part of the energy industry that is currently undergoing the greatest transformation. Increasingly, decarbonization efforts are focusing on electrical energy and it is assumed that GHG reductions will occur by gradually replacing more energy sources with low-carbon electricity [5]. For example, the European Green Deal sets a target for European Union countries to reduce GHG 
emissions by $55 \%$ by 2030 (vs. 1990 level) and completely by 2050, and $40 \%$ of energy consumed by 2030 is to be from renewable sources (vs. $21 \%$ in 2021). To meet such ambitious goals, future electrical energy systems must be better integrated with consumer behavior, and expertise from various domains must work in combination [6]. In the case of such a complex problem, relying solely on the research of a single discipline is rarely sufficient to develop an effective response $[7,8]$. The example of the transformation of two neighborhoods in the north of England from energy consumers to energy positive ones shows that a comprehensive approach that combines technological solutions with social conditions can be effective [9]. Therefore, we have adopted an interdisciplinary perspective, with consideration to economic, sociological, psychological, and technological concerns.

We look at measures that reduce household electricity demand and limit the load on the electric grid by shifting some demand from peak grid load hours to another time (DSM-Demand-side flexibility). Households can reduce their electric energy requirements by replacing appliances with less energy-intensive ones, by changing the way they use existing appliances, by enhancing thermal insulation of a building, by installing their own energy generation equipment, or by consuming less [10]. It is also possible to reduce electricity consumption by increasing the use of other sources of energy (e.g., heat from a combustion furnace), but we consider here actions leading to a reduction of the demand for energy supplied to the household, either by using it more efficiently or by self-generation of part of the energy with renewable sources. Individual consumers can also reduce their burden on the power grid by shifting their electric energy use away from peak hours. This flexible approach to electric energy consumption is of increasing importance in view of the growing share of renewable energy that is generated in fluctuating amounts, depending on current weather conditions [11].

Our main area of interest is the energy users' motivation behind the measures listed above. After reviewing the literature on electricity saving in households, we observe that there are a host of motives for such behavior [12]. Electrical energy conservation can be inspired by ecology - a desire to reduce one's carbon footprint, for instance [13]. Another reason is financial-namely, to reduce energy expenditure [14]. An interest in technology and the desire to own the latest products also play a role. The influence of the social environment is relevant to the discussion, including existing norms of behavior, as well as the values of and actions taken by family and friends [6,15]. Some studies reported the high awareness of individual energy consumers about the seriousness of the challenges of the climate crisis, and showed that at least part of the society may be ready to contribute part of their income to climate change mitigation policies $[16,17]$. Their motivations, however, can differ significantly: individuals might focus less on ecology and climate protection, and be more eager to make monetary savings; they might have a passion for technology; or, they might be conscious of the opinions of their peers. Understanding the motivations behind electrical energy saving among individual consumers is essential for the effective implementation and promotion of reforms to reduce the carbon footprint. Actions to save on energy expenditure or install renewable energy production equipment in residential homes might or might not be driven by the intention to reduce greenhouse gas emissions $[7,18]$. Furthermore, such actions might fail to lead to actual reductions in energy consumption and carbon footprint-particularly if individuals reduce energy expenditure in order to redirect those savings into other consumption [19]. Increases in the popularity of electrical energy saving actions accompanied by the perpetuation of the well-established consumption-growth path might prove inadequate in facing the impending environmental threats and the challenges of transforming the electrical energy market [20].

Our primary contribution to this discussion comprises consideration of the complex set of motivations that could increase the popularity of green solutions for electricity consumption and generation at households, in order to establish whether we are observing an ecological breakthrough, or a mere continuance of the well-trodden consumption-growth path. Most literature focuses on the determinants of electrical energy saving behaviors. We expand upon this common approach by additionally taking into consideration electrical 
energy production and storage installations, as well as interest in smart grid solutionsincluding those which complement the flexibility of electrical energy demand. Current studies are primarily based on analyses of single countries, whereas this article utilizes an original survey conducted on representative samples from Denmark, France, Italy, and Spain.

Our research aim and main focus is to analyze the motivations behind electrical energy conservation and smart management at the household level. This is an important topic of investigation, as introducing new smart grid solutions on a common scale requires acceptance and engagement of end users. We want to underline that a growth in energy efficiency does not have to lead to a decrease in total electricity demand, which we understand both directly (as a lack of the decrease due to larger use of a higher number of electrical energy-efficient devices in a household) and indirectly (using savings on electricity to fund higher consumption of non-electrical goods which still need energy at the stages of production and distribution). Therefore, it is crucial to distinguish between different motivating factors. If individual actions are driven solely by finance and aim at higher efficiency, it potentially leads to lower energy savings as the economizing on energy may translate to a higher general consumption. However, if ecological motivation is the major reason to save energy, households are more likely to reduce their total demand for electric energy and thus their total GHG emissions.

\subsection{The Paradox of Energy Efficiency and the Increase in Demand for Energy-Powered Services}

Effectively reducing demand for electric energy is a complex subject, which reaches well beyond the most commonly analyzed technological issues of energy efficiency and grid stability. A number of studies and real-world applications demonstrate that the use of technology to reduce energy demand through improved energy efficiency has limited effectiveness on a macro scale $[19,21]$. Energy efficiency is an important contributor to higher economic growth. This relationship is clearly demonstrated both by studies on panel data [22,23] and on individual economies [24,25]. More efficient energy use alters consumption patterns, and most often results in increased use of energy-demanding equipment and services [26]. As a result, energy-saving measures often prove less effective than anticipated, or, in some cases, have even proved counterproductive. This effect is apparent, for example, in the automotive sector, where the increase in car energy efficiency has not led to reduced fuel consumption, but to increased vehicle weight and engine power $[27,28]$. Research in Japan also shows that more fuel-efficient hybrid cars cover greater distances $[29,30]$. A similar phenomenon was observed by Wilson and Boehland in single-family house construction in the USA, where the space occupied by one person tripled from 1950 to 2004. For this reason, the increase in energy efficiency of the new houses was more than offset by their larger size [31].

Already in 1865, William Stanley Jevons, in his renowned article, The Coal Question, highlighted that the more efficiently coal is used, the larger the total demand for coal becomes; and not, as was then commonly believed, the opposite. As the cost of operating coal-powered steam engines decreased, they became more widely used, which led to a rapid increase in demand for the technology, and, consequently, an increase in total coal consumption $[32,33]$.

Modern literature alludes to a similar phenomenon, known as the rebound effect. Lower energy requirements increase the economic effectiveness of a given service or technology, but simultaneously increase the demand for it [34-36]. This effect is stronger in economies with high wages and low energy prices, when technological change also brings other positive effects, such as time savings [34]. There is no consensus in the literature on the significance of the rebound effect on the net effectiveness of energy-saving measures. Some researchers believe that it is a phenomenon of minor importance [37]; others claim that the rebound effect could be even greater than the scale of energy reduction $[32,38]$. Sorrel estimates that for household energy services in OECD countries the rebound effect should be below 30\% [39], Brockway reports that the economy-wide rebound effect typically 
exceeds 50\% [40]. Wei's work, based on a computable general equilibrium (CGE) model, estimates an even higher rebound effect, at a level of 70\% [41].

From the point of view of this article, however, more important than the overall energy balance are the motivations leading to measures to improve energy efficiency. William Rees, commenting on the currently dominant measures to guarantee sustainable economic development (green buildings, hybrid and electric cars, green consumerism) argues that their fundamental problem is that they try to maintain the status quo by other means. He believes that efforts to maintain a lifestyle typical of developed economies are doomed to failure because this lifestyle is based on unsustainable values-the constant pursuit of increasing wealth and meeting all needs, including those created by the market economy. From this point of view, the weak point of efforts to increase energy efficiency is the assumption that the ever-increasing needs must be met in a more energy-efficient manner, without questioning the legitimacy of the needs themselves. Thus, by lowering the cost of energy use, energy efficiency efforts increase the demand for energy-powered services and strengthen dependency on their availability [42].

A similar criticism applies to measures that increase the elasticity of energy demand. The daily, weekly, and annual time patterns of electrical energy use correspond to the social rhythms of activity, shaped by decades of the development of modern societies $[43,44]$. Technology that increases the elasticity of energy demand, while maintaining a commitment to enable the consumption of services with unchanged quality, fails to alter the established patterns of behavior; thus, purely technological solutions make energy demand more flexible, but do not modify demand for the conveniences that the energy enables. By overlooking the importance of social arrangements and relationships, the current rhythm of the use of energy-powered services is maintained, or even reinforced [45]. As a result, the demand for services that require energy remains steady, or even increases [46]. This leads to similar problems as described above in which improvements in the efficiency of energy use may consolidate energy consumption patterns-or even increase, rather than decrease, total energy consumption [33].

Both the rebound effect and the consolidation of the rhythm of electricity consumption by demand-side technology are examples that the technological capacity to reduce energy consumption alone is insufficient if consumers are not motivated to reduce their overall use of electricity. Therefore, understanding the motivations of electricity users is important to determine their acceptance potential for reducing the total level of electricity consumption, and not only for using it more efficiently.

\subsection{Factors Driving Energy-Saving Behaviors and Intentions}

This section presents the chief determinants of actions and intentions pertaining to energy saving that can potentially lead to reductions in energy consumption or increases in the flexibility of energy demand.

\subsubsection{Ecological Motivation Based on Environmental and Climate Awareness}

Ecological awareness is frequently presented as a key instrument in reducing the carbon footprint, by implementation of smart grid solutions and saving energy [47,48], the installation of photovoltaic panels [49], and receptivity to 'low-carbon energy' ideas [50]. Research indicates that for a substantial portion of individuals, concern about the state of the natural environment influences their energy use decisions significantly. Pro-environmental behavior is often associated with altruistic values, a focus on how to reward others and wider communities, and biospheric values in which individuals focus on the effects of actions that have an ecological impact [51]. According to Schwartz, for those whose decisions are guided by environmental factors, supplementing ecological solutions with monetary rewards can even reduce their willingness to use them [52]. 


\subsubsection{Financial Motivation}

Attitudes towards energy use and environmental behavior can be also shaped by finances, and might manifest themselves in attempts to reduce energy bills, for instance. This is an egoistic motivation-one that is centered on self-interest; and may involve allowing circumstances to deteriorate in the short term in order to maximize long term gains [51]. Interestingly, in opposition to altruistic motives, the desire to save money was found to be irrelevant to pro-environmental behavior [48]. Moreover, experiments on energy conservation incentives have proved that individuals who are driven by financial incentives react primarily to monetary feedback (how much less they have to pay), and are not motivated by discovering the amount of energy they have saved, or the benefits to the environment [53].

\subsubsection{Technology}

One factor that influences energy-saving behavior is an attitude towards technology. Reluctance to adopt new energy-saving solutions may be caused by an unwillingness to take the risk that an investment might not 'pay off' [54]. Other concerns regarding new technologies connected to the internet and devices managed remotely-such as smart home technologies - are privacy issues, security, and the compatibility of equipment [55].

Nevertheless, users of new technologies experience a sense of prestige and project a social image of modernity. Owning and being familiar with technological novelties is also frequently associated with higher expenditures-novelties cost more. The innate willingness to pay for innovative products is preceded by higher income, a positive attitude towards status symbols, and procession of an orientation towards spending rather than saving [56].

\subsubsection{Social Context}

There is much evidence from the literature that social norms and interactions, particularly those that exist in local communities and in the closest social environments, can affect environmental attitudes and behaviors [47,48]. This can be seen in the diffusion of innovative ideas [57], such as the geographical clustering of solar photovoltaic panel use. This is caused by peer effects and the marketing that utilizes them [58].

Interestingly, for the adoption of smarter energy habits, the most influential relationships are those that involve the strongest ties: relatives have the most influence, followed by friends, and the opinions of work colleagues and experts are the least relevant [59]. Additionally, transmission of pro-environmental behaviors within families has an intergenerational character, and the convergence is observed primarily in mutually visible, shared areas of homes, such as kitchens and living rooms [60].

Different specific social mechanisms can be connected with the peer effects observed in household behaviors when discussing the social influence underlying energy-related decisions; it begins with interpersonal communication and social learning among peers, and is supplemented by the role of social norms [61]. Some attempts have been made, in the context of energy consumption, to distinguish the mechanism of social influence from that of homophily, using an approach based on analysis of social network dynamics [62]. The general conclusion is that embeddedness in a social environment cannot be omitted in explaining the determinants of energy saving behaviors. This can affect energy behavior and intentions both directly and indirectly, influencing the attitudes and their motivating factors.

\subsubsection{Hedonistic Attachment to Comfort}

As discussed in Section 1.2., economizing energy can act as an instrument for enabling increases in individual consumption that lead to higher personal satisfaction. Curiously, receiving feedback that focuses on the value of the energy consumed (or not consumed) may serve to increase electricity consumption [63]. This likely occurs because consumers are made aware of the low price of energy, and are thus more prone to increasing their use 
of it. Such an incentive should work not only for those with the aforementioned egoistic intentions-individuals who are focused on long-term individual benefits, but are also driven by hedonistic desires; on improving their current circumstances, and on maximizing the pleasure that can be achieved 'here and now' [64]. Such an attachment to comfort correlates with a tendency to seek out new technological solutions, provided that they enable the user to achieve higher current consumption. Simultaneously, this might act as a barrier against energy-saving behaviors, if those behaviors are connected with restrictions and inconvenience. Research indicates that individuals with hedonistic motivations have a lower tendency to save [53], and are less conformant to environmental values [64]. In addition to influencing consumers' energy habits and intentions directly, attachment to comfort also impacts their ecological, financial, and technological incentives.

\subsubsection{Values, Life Goals, and Lifestyles}

As mentioned in Sections 1.2.1, 1.2.2 and 1.2.5, energy use, conservation, and the motivations behind associated behaviors are embedded in personal values. Hedonistic values have been found to negatively influence pro-environmental attitudes, preferences, and actions [64]; while biospheric values offer the strongest and most unconditional motivation to save energy $[53,64]$. Those values also underlie individual life goals and lifestyles, which, in connection with situational factors and habits, constitute an important tool for explaining energy-saving behaviors [65]. We claim that both traditional and modern ways of life can be receptive to incentives for pro-environmental actions and intentions; the first being connected with attachment to nature, and the second with inclination towards following trends and adopting new technologies. New solutions for energy saving and flexibility must complement existing patterns, lifestyles, and habits.

\subsection{Research Hypotheses and the Model Conceptualization}

Based on the literature review presented in this section, we believe behaviors and intentions regarding energy use to be determined by a set of complex motivational relationships between ecology, finance, eagerness towards new technologies, social environment, attachment to comfort, life goals, attitudes towards the climate crisis, and socio-demographic backgrounds. These factors are illustrated in Figure 1.

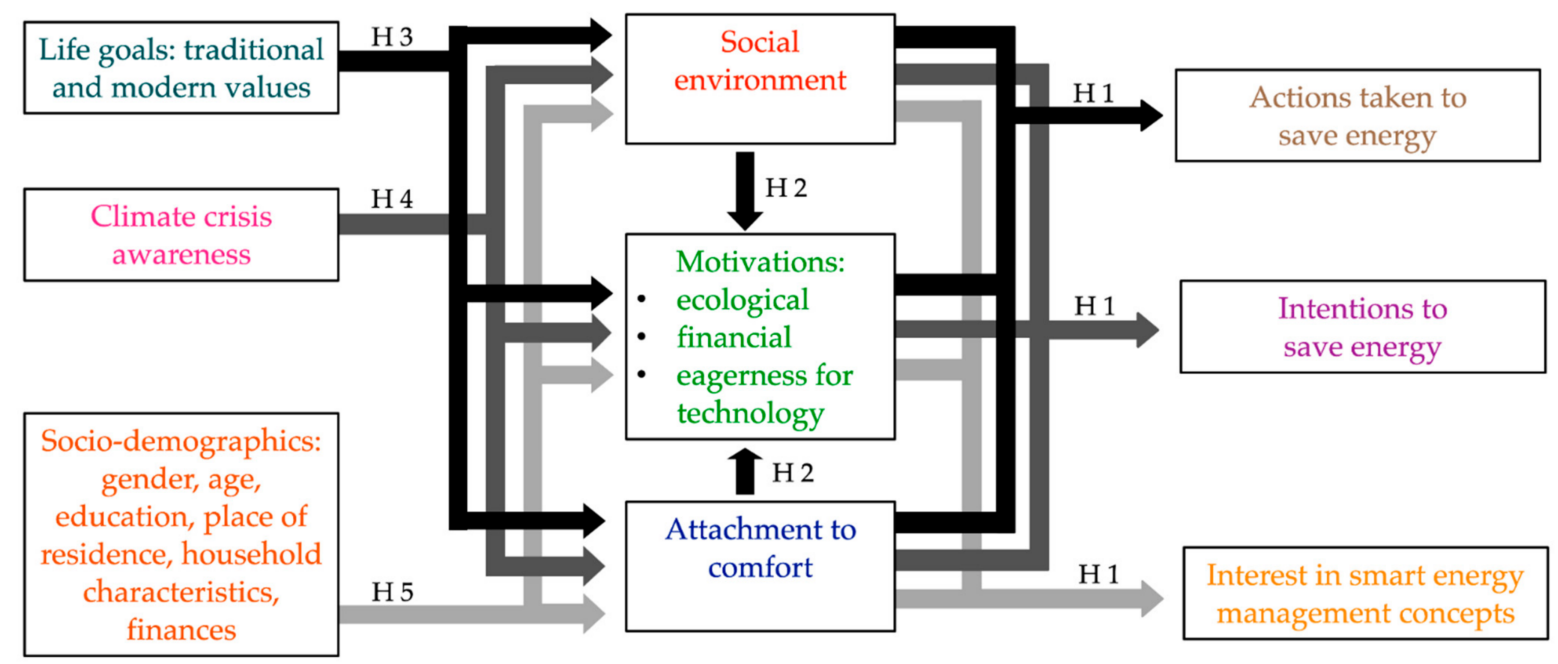

Figure 1. Determinants of energy-saving behaviors and intentions.

The reasoning behind this conceptualization is to enable broad and thorough analysis of pro-environmental behaviors and intentions in the context of energy use, with consideration for different potential motivations, and also to encompass the underlying factors in which they are embedded. Such an approach is in accordance with the current state 
of art, which stresses the importance of the multiplex research framework [47,48,66-68]. We drew inspiration from several economic, psychological, and sociological behavioral models, including classical decision-making models, such as the Theory of Reasonable Action, the Theory of Planned Behaviour, and the Norm Activation Model [68,69]; as well as the potential role of social influence [70], which is observable as peer effects pertaining to the adoption of pro-environmental solutions [58]. Additionally, we considered the contemporary approaches of various research traditions, including conventional economics, behavioral economics, social psychology, sociology, and technology diffusion $[47,71]$. These approaches differ significantly in their assumptions, variables considered, and structure; there is no single, universal method of depicting the decision-making process. Key groups of factors which influence decisions, however, can be distinguished, such as attitudes, social norms, values, economic criteria, and demographic characteristics. While preparing the structural model used in this study, we scrutinized the decision determinants reported in earlier works to assess their influence on a range of actions and intentions that represent different aspects of openness to smart energy management solutions.

Our logic is to cover not only current households' behaviors and implemented so far solutions regarding energy conservation (actions taken to save energy) but also readiness for such behaviors and implementations in the future (intentions to save energy) and openness for new, not yet functioning, smart grid ideas (interests in smart energy management concepts). We additionally distinguish between direct reasons and obstacles for those behaviors and intentions (those connected with impact of social environment, ecological, financial, connected with eagerness for new technologies, and attachment to comfort) and indirect factors, creating exogenous, earlier established, background in which energy end users' decisions are taken (covering life goals based on general values, specific values regarding the environment connected with climate crises awareness, and sociodemographics). Additionally, we assume that the social environment does not only affect the behaviors and intentions directly (social networks serve as a source of information and examples to follow) but also indirectly, as it has an influence on attitudes (individual energy-conservation motivations regarding ecology, finance and openness for new technologies). Similarly, attachment to comfort is not only a decision factor regarding behaviors and intentions, but also impacts motivations (may be detrimental for the ecological concerns, but may correspond with economizing on energy to finance other consumption, and may go hand in hand with eagerness for new technologies which often are aimed to make life easier).

Our motivations (ecological, financial, and eagerness to technology) correspond with attitudes from the theory of planned behavior (TPB) [72], but also are inspired by the norm activation model (NAM) [73,74], as we connect ecological reason with altruistic behavior. Our recognition for the importance of the social environment is in accordance with the idea of the subjective norm from TPB [72] but also is related to the theory of social influence [70]. Additionally, we take into consideration attachment to comfort and consumption. As connected with hedonistic motivation, this one should generally be a barrier for energy saving $[53,64]$. It is expected to be detrimental towards actions leading to energy demand reduction, but still it may support actions towards increasing electrical energy efficiency. Therefore, it may go hand in hand with interest in some energy-saving solutions if they enable increase in general consumption and consumer satisfaction.

As an indirect factor, we consider values, following in this aspect the value-attitudebehavior hierarchy model (VAB) [75]. As in the value-belief-norm theory (VBN) [76], we distinguish between biospheric values connected with environmental concern and other values that can also affect personal norms, which follows the approach proposed in a study of psychological and socio-demographic factors related to household energy use and saving intentions [77]. In accordance with TPB, we assume the indirect influence of socio-demographics on energy saving actions and intentions [78]. We do not include TPB theory's perceived behavioral control as a direct determinant, but we partially take it 
into consideration as an indirect factor, as a part of climate crisis awareness (convictions regarding the possibility of effective climate-change-mitigation actions).

We pose the following hypotheses, which are in accordance with the proposed model of dependencies:

Hypothesis 1 (H1). Actions taken to save energy, intention to engage in such actions, and interest in smart energy management concepts are determined by both ecological and financial factors, as well as openness to new technologies, social environment (the social networks in which the respondents engage), and attachment to comfort and consumption.

Hypothesis 2 (H2). Motivations: ecological, financial, and eagerness to adopt new technologies are influenced by social networks and attachment to comfort and consumption.

Hypothesis 3 (H3). Life goals (traditional and modern values) influence in which social networks the respondents engage, their motivations, and attachment to comfort and consumption.

Hypothesis $4 \mathbf{( H 4 ) . ~ C l i m a t e ~ a w a r e n e s s ~ i n f l u e n c e s ~ i n ~ w h i c h ~ s o c i a l ~ n e t w o r k s ~ r e s p o n d e n t s ~ e n g a g e , ~}$ their motivations, and attachment to comfort and consumption.

Hypothesis 5 (H5). Gender, age, education, place of residence, household characteristics, and financial conditions influence in which social networks respondents engage, their motivations, and attachment to comfort and consumption.

\section{Materials and Methods}

\subsection{Data Source}

The data was obtained during an online survey in June 2020, conducted with the support of IQS Poland, a research agency, and addressed to respondents in four countries: France, Spain, Italy, and Denmark. The survey was completed by 3200 respondents (800 in each of the countries). Random-quota sampling was employed, and the amounts were set for variables including age, gender, size of the place of residence, education level, and region.

The target group consisted of respondents who were responsible or co-responsible for paying electricity bills or purchasing electrical appliances in their households. The sample was gender-balanced ( $51 \%$ women and $49 \%$ men), and covered respondents aged 18-65 years (the average age in the sample was 42 ).

The questionnaire was designed to gather a wide range of information on respondents' use of electricity. The subjects it covered included equipping homes and workplaces with electrical appliances; ownership and opinion on electricity production and storage devices; perception of current electricity prices; factors influencing energy saving; potential for purchase of electric cars; and attitudes towards technology, the environment, and energy transformation in the European Union. The questionnaire also assessed three concepts of smart grid technology-automatic lighting control, external washing machine control, and external charging control for an electric car. It reached beyond the notion of energy saving in itself, and assessed solutions that reduce the load on the energy network-both by reducing energy consumption, and by shifting energy consumption to off-peak periods (energy flexibility).

\subsection{Description of Variables}

\subsubsection{Actions Taken to Save Energy}

Individual actions to save energy can regard direct use of electricity, gas, and fuel and additionally may include indirect measures, associated with production, distribution and disposal of consumed goods [18]. Our main focus is on the direct electricity consumption's patterns of households, but we also cover chosen aspects of general direct energy saving, when it is connected with electrical energy management and openness to new technological 
solutions (like installation of heat pump or recuperator). We make this simplification as the context of our analysis is about challenges regarding smart electricity management, which should lead both to decrease in electrical energy consumption and increase in flexibility within the time of its use. Implementation of such solutions needs acceptance on the household level. Another reason for the focus on household electricity management is that an important part of the decarbonization strategy for the economy is based on the development of clean electrical energy and the electrification of energy services currently provided to households in other ways (e.g., transport, heating) [5,79]. The same logic stands behind the choice of variables discussed in Sections 2.2.2 and 2.2.3.

We approximated actions taken to save electricity by an aggregate variable, 'electrical energy saving' (ranging between 0 and 18), which was constructed as the sum of the following ordinal variables (0-'definitely not'; 1 -'rather not'; 2-'rather yes'; 3-'definitely yes'. 'Don't know/hard to say' indicating the absence of data):

- Control of energy spending ('It is important for me to control exactly how much I spend on electricity');

- Attention to price ('I pay attention to the price of $\mathrm{kWh}^{\prime \prime}$ );

- Checking the meter ('I check the electricity meter on my own to control consumption');

- Attempts to save electricity ('As much as I can, I try to save electricity');

- Warning others ('I warn others when they waste electricity');

- Buying energy efficient appliances ('When buying consumer electronics, I consider the energy efficiency labels').

We justified the construction of this aggregate variable by performing a statistical procedure, based on a nonparametric item response theory model, to ensure that the listed statements comprised a Mokken scale [80,81]. This method assumes the existence of a latent trait that differs between respondents, and cannot be observed directly. The model predicts a cumulative scale, which means that low levels of latent variables are measured by more common behaviors, such as attempts to save electricity; high levels are measured by less common behaviors, such as checking the meter. Different behaviors belong to the same scale if the fact that respondents engage in less common behaviors indicates that they also engage in more common behaviors, and all responses that fail to conform to this pattern result only from random errors. As soon as the scale is identified, it is possible to construct a cumulative indicator by aggregating the individual answers belonging to a given scale. This can be then treated as an interval variable.

Another aspect of energy saving we consider is the installation of facilities to generate and store electricity, as well as devices limiting the demand for electricity from the network. We utilized the binary variable, 'prosumers', which scored 1 one if a respondent had at least one of the following installations: photovoltaic panels, wind microturbine, water microturbine, energy storage system, solar water heating, heat pump, recuperator, or solar collectors.

\subsubsection{Intentions to Save Energy}

'Ecocar planned' is a binary variable that scored 1 if a respondent intended to buy a hybrid, plug-in-hybrid, or fully electric car within the next two years.

'Saving by behavior' is a binary variable that scored 1 if a respondent was considering at least one of the following actions:

- Reducing consumption without additional equipment;

- Reducing stand-by consumption;

- Switching off appliances when they are not in use.

'Major investments' is a binary variable that scored 1 if a respondent was considering at least one of the following actions:

- Photovoltaic installation;

- Solar collectors for domestic water heating;

- Installing heat pumps; 
- Recuperation (ventilation);

- Insulating the façade of his/her home.

'Minor investments' is a binary variable that scored 1 if a respondent was considering at least one of the following actions:

- Replacing appliances in the home with energy efficient alternatives;

- Purchasing energy efficient devices.

\subsubsection{Interest in Smart Energy Management Concepts}

The respondents were presented with three concepts intended to decrease electrical energy consumption and to reduce the load on the power grid during peak hours: automatic lighting control in the home, external washing machine control, and external charging control for an electric car. 'Interest in concepts' is a count of the concepts in which respondents declared an interest. Interest in these three concepts was highly correlated, and the answers were confirmed to behave in accordance with the Mokken model.

\subsubsection{Social Environment}

The potential influence of the interactions within social networks was included as an aggregate variable, 'social environment' - a scale ranging from 0 to 8 . It considers a set of binary variables that indicate: (1) talking about saving electricity with family members; (2) talking about saving electricity with friends; (3) talking about saving electricity with colleagues from work or school; (4) talking about saving electricity with neighbors; (5) talking about saving electricity with sales people or technical experts; (6) talking about saving electricity with further acquaintances and others; (7) at least a few friends and family members taking action to reduce the cost of energy consumption; and (8) seeking information on how to reduce energy consumption. All of the items were confirmed to create a scale in accordance with the Mokken model.

Additionally, there were three binary variables included that indicate types of energysaving actions that respondents had observed among their friends and family members:

- 'friends save by behavior';

- 'friends major investors';

- 'friends minor investors'.

These variables were constructed analogously to those described above, which concerned respondents' intentions towards energy saving.

\subsubsection{Ecological Motivation}

Respondents were asked to mark up to three reasons to save electrical energy that were applicable to themselves. The binary variable, 'ecological reason' scored 1 if among the three reasons, a respondent selected one of the following: (1) to reduce negative environmental impact; (2) to improve energy security in the region or place of residence (such as a municipality, city, or district); (3) to reduce $\mathrm{CO}_{2}$ emissions; or (4) social responsibility (future children and grandchildren).

\subsubsection{Financial Motivation}

The binary variable, 'financial reason' scored 1 if among the three main reasons to save electric energy, a respondent selected one of the following: (1) to reduce electricity expenses (lower bills); or (2) 'I am generally a frugal person'.

\subsubsection{Eagerness for Technology}

The binary variable, 'eager new tech' pertains to having a liking for technological novelties. It scored 1 if respondents claimed that, among the people they know, they were the first to experiment with new products and solutions, or decided to use them soon after discovering their existence. They did not need to be aware of at least a few 
positive experiences from other people, and they did not wait until their peers had adopted novel solutions.

\subsubsection{Attachment to Comfort}

Attachment to comfort (and thus, consumption) was measured by a count of devices assessed by respondents as necessary for survival. 'Comfort attachment' scores range between 0 and 11, and consist of the following items: fridge, washing machine, lights, microwave, TV set, audio set, computer, mobile phone, air conditioning, heating, and air filter/humidifier. All of the items were confirmed to create a scale in accordance with the Mokken model.

\subsubsection{Life Goals: Traditional and Modern Values}

Respondents were asked how important various life goals were to them: (1) a happy family and devoted friends; (2) love and happiness in relation to another person; (3) compliance with their own principles, adhering to a moral code, (4) intellectual development; (5) self-realization; (6) ensuring good material status for themselves or their loved ones; (7) cheerfulness; (8) living according to nature and respecting its rights; (9) prestige; (10) recognition of and respect for the environment; (11) being respected and admired by other people; (12) feeling part of a group or community; (13) a peaceful life away from the hustle and bustle and civilization; (14) spiritual development; (15) a life full of excitement; (16) living on time, in modernity and current trends of civilization; (17) competition and success; (18) enjoying the charms of a big city; (19) health and physical well-being; and (20) security - having no fear about the future. By utilizing a method adjusted to the ordinal variables using factor analysis, two latent traits were identified, and accordingly, two appropriate measures were established: the first indicating a focus on modern values ('modern val'), which was most closely associated with prestige, being respected and admired by other people, living a modern life, competition and success, and enjoying the charms of a big city; and the second indicating a focus on traditional values ('traditional $\left.\mathrm{val}^{\prime}\right)$, for those who scored highly in the remainder of the items.

\subsubsection{Climate Crisis Awareness}

To account for climate awareness, two aggregate variables were constructed as a sum of the ordinal variables (0-'definitely not'; 1-'rather not'; 2-'rather yes'; and 3-definitely yes. 'Don't know/hard to say' indicated the absence of data), both of which established scales between 0 and 12, in accordance with the Mokken model. The first variable is 'awareness of climate', which consists of the following items pertaining to the perceived consequences of climate change: (1) 'will cause extreme weather fluctuations and other natural disasters in [France/Denmark/Spain/Italy] (e.g., floods or droughts)'; (2) 'will pose serious problems for animal and plant species and their environment'; (3) 'will have a negative impact on my health and well-being'; and (4) 'will generally be a very serious problem for my family and I'. The second, 'climate change denial', is based on the following statements: (1) 'I don't focus my attention on news and data about problems like climate change'; (2) 'I don't think much about the problems of the distant future, such as the impact of climate change'; (3) 'In my opinion, not much can effectively be done to mitigate climate change'; and (4) 'The $\mathrm{CO}_{2}$ emissions of my country do not have a significant impact on the global scale of climate change'.

'Declaration to pay' is a binary variable that scored 1 for respondents who would accept a $€ 50$ reduction in their monthly income if it enabled implementation of the EU energy transition plan, which assumes a 50\% reduction in EU greenhouse gas emissions by 2030, and a complete phasing out of fossil fuel use by 2060.

\subsubsection{Socio-Demographic Controls}

Several variables were included to control the role of the following socio-demographic characteristics: gender ('female' scored 1 for women); 'age' (a continuous variable); ed- 
ucation ('higher education' scored 1 if respondents or their partners/spouses attended university, even without obtaining a degree); place of residence (binary variables indicating whether respondents lived in a 'big city' of over 500,000 inhabitants, or a 'village', with the reference group in between); household characteristics ('household size'-the number of people living in a household, including the respondent, living in a 'house' and owning their 'own home'); financial conditions ('rich' for respondents stating that they lived very well and could afford a lot without saving money, or even afford luxuries; and 'poor' for respondents assessing their standard of living as modest, being required to spend money carefully every day, or even experiencing poverty-having insufficient means even for basic needs; with a reference group who had an average standard of living and could meet everyday expenditures, but were required to save for major purchases).

\subsection{GSEM Model Specification}

We utilized generalized structural equation modelling (GSEM) [82] to verify the set of hypotheses presented. This approach enabled us to simultaneously test the motivations of different energy use behaviors and intentions, as well as the factors determining them, while accounting for the predicted interconnections between the variables.

Figure 2 presents a path diagram incorporating all of the equations that were simultaneously estimated within the GSEM framework. For the binary dependent variables, ('prosumers', 'ecocar planned', 'saving by behavior', 'major investments', 'minor investments', 'friends save by behavior', 'friends major investors', 'friends_ minor investors', 'ecological reason', 'financial reason', and 'eager for tech'), logistic regressions were estimated. For a single ordinal dependent variable ('interest in concepts'), ordinal logistic regression was employed. For the continuous dependent variables ('electrical energy saving', 'social environment', and 'comfort attachment'), linear regressions were used. The calculations were performed using a maximum-likelihood estimator. Accounting for differences between the respondents from different countries and the correlations between observations within such groups, standard errors were corrected by clustering observations by country.
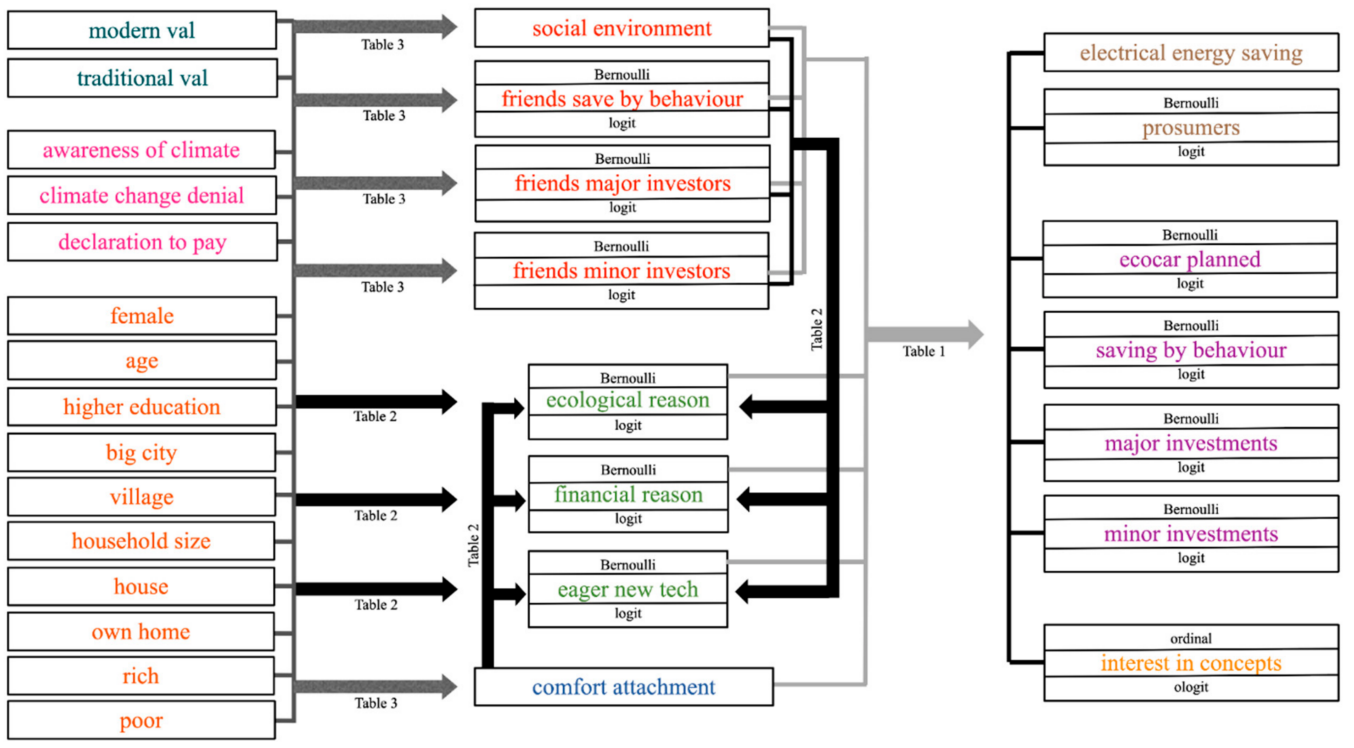

Figure 2. GSEM path diagram.

\section{Results}

The results of the estimations are presented in Tables 1-3. The findings we discuss below regard the investigated sample of the survey conducted, however, as the sample was 
representative for the populations of the included four countries, a cautious generalization is justified.

Table 1. Results from the GSEM, part I. Authors' own analysis, based on data obtained during an online survey performed in four countries. $+p<0.10,{ }^{*} p<0.05,{ }^{* *} p<0.01,{ }^{* * *} p<0.001$, the standard errors clustered in countries are reported in parentheses.

\begin{tabular}{|c|c|c|c|c|c|c|c|}
\hline & $\begin{array}{c}\text { Electrical Energy } \\
\text { Saving }\end{array}$ & Prosumers & $\begin{array}{c}\text { Ecocar } \\
\text { Planned }\end{array}$ & $\begin{array}{l}\text { Saving by } \\
\text { Behavior }\end{array}$ & $\begin{array}{c}\text { Major } \\
\text { Investments }\end{array}$ & $\begin{array}{c}\text { Minor } \\
\text { Investments }\end{array}$ & $\begin{array}{c}\text { Interests } \\
\text { in Concepts }\end{array}$ \\
\hline $\begin{array}{c}\text { social } \\
\text { environment }\end{array}$ & $\begin{array}{c}0.710^{* * *} \\
(0.034)\end{array}$ & $\begin{array}{c}0.172^{* * *} \\
(0.02)\end{array}$ & $\begin{array}{c}0.217^{* * *} \\
(0.022)\end{array}$ & $\begin{array}{c}0.125^{* * *} \\
(0.029)\end{array}$ & $\begin{array}{c}0.208^{* * *} \\
(0.025)\end{array}$ & $\begin{array}{c}0.214^{* * *} \\
(0.053)\end{array}$ & $\begin{array}{c}0.268^{* * *} \\
(0.018)\end{array}$ \\
\hline $\begin{array}{l}\text { friends save } \\
\text { by behavior }\end{array}$ & $\begin{array}{l}-0.106 \\
(0.216)\end{array}$ & $\begin{array}{c}-0.164 * \\
(0.076)\end{array}$ & $\begin{array}{l}-0.024 \\
(0.155)\end{array}$ & $\begin{array}{c}0.701 * * * \\
(0.034)\end{array}$ & $\begin{array}{l}-0.046 \\
(0.105) \\
\end{array}$ & $\begin{array}{c}0.023 \\
(0.083) \\
\end{array}$ & $\begin{array}{l}0.192 \\
(0.15) \\
\end{array}$ \\
\hline $\begin{array}{l}\text { friends major } \\
\text { investors }\end{array}$ & $\begin{array}{c}-0.358^{* *} \\
(0.117)\end{array}$ & $\begin{array}{c}0.528 * * * \\
(0.083)\end{array}$ & $\begin{array}{c}0.173^{* * *} \\
(0.036)\end{array}$ & $\begin{array}{l}-0.058 \\
(0.106)\end{array}$ & $\begin{array}{c}0.953^{* * *} \\
(0.066)\end{array}$ & $\begin{array}{c}0.007 \\
(0.069)\end{array}$ & $\begin{array}{l}0.206 * \\
(0.091)\end{array}$ \\
\hline $\begin{array}{l}\text { friends minor } \\
\text { investors }\end{array}$ & $\begin{array}{c}0.220^{* * *} \\
(0.034)\end{array}$ & $\begin{array}{l}-0.012 \\
(0.093)\end{array}$ & $\begin{array}{c}0.328^{* *} \\
(0.118)\end{array}$ & $\begin{array}{l}0.305 * \\
(0.127)\end{array}$ & $\begin{array}{l}-0.039 \\
(0.088)\end{array}$ & $\begin{array}{c}0.958^{* * *} \\
(0.072)\end{array}$ & $\begin{array}{c}0.072 \\
(0.073)\end{array}$ \\
\hline $\begin{array}{l}\text { ecological } \\
\text { reason }\end{array}$ & $\begin{array}{l}0.470 * * \\
(0.159)\end{array}$ & $\begin{array}{l}0.269 * \\
(0.106)\end{array}$ & $\begin{array}{c}0.370 * * * \\
(0.079)\end{array}$ & $\begin{array}{c}0.411^{* * *} \\
(0.085)\end{array}$ & $\begin{array}{l}0.524^{* * *} \\
(0.024)\end{array}$ & $\begin{array}{c}0.396^{* * *} \\
(0.049)\end{array}$ & $\begin{array}{c}0.397 * * \\
(0.128)\end{array}$ \\
\hline $\begin{array}{l}\text { financial } \\
\text { reason }\end{array}$ & $\begin{array}{c}0.808^{* * *} \\
(0.216)\end{array}$ & $\begin{array}{c}-0.329^{* * *} \\
(0.098)\end{array}$ & $\begin{array}{l}-0.056 \\
(0.051)\end{array}$ & $\begin{array}{c}0.720^{* * * *} \\
(0.109)\end{array}$ & $\begin{array}{c}-0.463^{* * *} \\
(0.062)\end{array}$ & $\begin{array}{l}0.261+ \\
(0.135)\end{array}$ & $\begin{array}{l}0.184 * \\
(0.072)\end{array}$ \\
\hline $\begin{array}{c}\text { eager } \\
\text { new tech }\end{array}$ & $\begin{array}{c}0.518^{* * *} \\
(0.149)\end{array}$ & $\begin{array}{c}0.384^{* * *} \\
(0.087)\end{array}$ & $\begin{array}{c}0.572 * * * \\
(0.062)\end{array}$ & $\begin{array}{l}-0.015 \\
(0.087)\end{array}$ & $\begin{array}{c}0.321^{* * *} \\
(0.088)\end{array}$ & $\begin{array}{c}0.116 \\
(0.076)\end{array}$ & $\begin{array}{c}0.572 * * * \\
(0.032)\end{array}$ \\
\hline $\begin{array}{c}\text { comfort } \\
\text { attachment }\end{array}$ & $\begin{array}{l}0.094+ \\
(0.052)\end{array}$ & $\begin{array}{l}0.002 \\
(0.01)\end{array}$ & $\begin{array}{c}0.059 * * * \\
(0.007)\end{array}$ & $\begin{array}{c}0.033^{* * *} \\
(0.007)\end{array}$ & $\begin{array}{c}0.003 \\
(0.016)\end{array}$ & $\begin{array}{c}0.021 \\
(0.016)\end{array}$ & $\begin{array}{c}0.057^{* * *} \\
(0.009)\end{array}$ \\
\hline constant & $\begin{array}{c}8.044^{* * *} \\
(0.548)\end{array}$ & $\begin{array}{c}-1.536^{* * *} \\
(0.166)\end{array}$ & $\begin{array}{c}-2.519 * * * \\
(0.146)\end{array}$ & $\begin{array}{c}-0.793^{* * * *} \\
(0.172)\end{array}$ & $\begin{array}{c}-1.740^{* * *} \\
(0.137)\end{array}$ & $\begin{array}{c}-1.789 * * * \\
(0.12)\end{array}$ & \\
\hline cut point $(y=1)$ & & & & & & & $\begin{array}{c}0.209 \\
(0.269)\end{array}$ \\
\hline cut point $(y=2)$ & & & & & & & $\begin{array}{c}1.323^{* * *} \\
(0.269)\end{array}$ \\
\hline cut point $(y=3)$ & & & & & & & $\begin{array}{c}2.468^{* * *} \\
(0.309)\end{array}$ \\
\hline observations & 2269 & 3200 & 3200 & 3200 & 3200 & 3200 & 3200 \\
\hline
\end{tabular}

Table 1 illustrates the findings pertaining to Hypothesis 1, including the direct factors that were predicted to influence actual and considered electrical energy-saving actions and interest in smart grid concepts: ecological reasons, financial reasons, eagerness for technology, social environment, and attachment to comfort. All of the pro-environmental energy use behaviors and intentions in the use of electricity in homes we analyzed were revealed to be related to ecological reasons, which conforms with findings from the literature [47-49]. As we found out, financial reasons play a less significant and less straightforward role: they cohere with actual electrical energy-saving behaviors and intentions to save electrical energy by behavior, as well as interest in smart energy management concepts; but correlate negatively with actual and planned saving by major investments. This corresponds with research stating that financial reasons, in contrast to ecological reasons, are inconsequential for pro-environmental behaviors [48]. Openness to technology matters in almost all actual and planned actions, including electrical energy-saving behaviors, installing equipment to reduce energy demand from the network, planning the purchase of ecological cars, intentions of major pro-environmental investments, and interest in concepts. This confirms findings from the literature regarding the importance of trust towards novel solutions [54,55]. 
Table 2. Results from the GSEM, part II. Authors' own analysis, based on data obtained during an online questionnaire completed in four countries. $+p<0.10,{ }^{*} p<0.05,{ }^{* *} p<0.01,{ }^{* * *} p<0.001$, the standard errors clustered in countries are reported in parentheses.

\begin{tabular}{|c|c|c|c|}
\hline & Ecological Reason & Financial Reason & Eager New Tech \\
\hline social environment & $\begin{array}{c}0.108^{* * *} \\
(0.025)\end{array}$ & $\begin{array}{c}0.076 \\
(0.063)\end{array}$ & $\begin{array}{c}0.104^{* * *} \\
(0.025)\end{array}$ \\
\hline \multirow{2}{*}{$\begin{array}{l}\text { friends save by } \\
\text { behavior }\end{array}$} & $0.308^{* *}$ & $0.297 *$ & 0.09 \\
\hline & $(0.099)$ & $(0.148)$ & $(0.072)$ \\
\hline \multirow{2}{*}{$\begin{array}{l}\text { friends major } \\
\text { investors }\end{array}$} & 0.246 & $-0.270 * * *$ & 0.113 \\
\hline & $(0.15)$ & $(0.049)$ & $(0.106)$ \\
\hline \multirow{2}{*}{$\begin{array}{l}\text { friends minor } \\
\text { investors }\end{array}$} & $0.156^{*}$ & 0.194 & 0.064 \\
\hline & $(0.063)$ & $(0.204)$ & $(0.103)$ \\
\hline comfort attachment & $\begin{array}{l}-0.011 \\
(0.024)\end{array}$ & $\begin{array}{l}0.063+ \\
(0.032)\end{array}$ & $\begin{array}{l}0.041 \text { * } \\
(0.017)\end{array}$ \\
\hline modern val & $\begin{array}{c}-0.056^{* *} \\
(0.021)\end{array}$ & $\begin{array}{l}-0.101 \\
(0.065)\end{array}$ & $\begin{array}{c}0.311^{* * *} \\
(0.037)\end{array}$ \\
\hline traditional val & $\begin{array}{c}0.109 * * * \\
(0.032)\end{array}$ & $\begin{array}{c}0.337^{* * * *} \\
(0.091)\end{array}$ & $\begin{array}{l}-0.026 \\
(0.043)\end{array}$ \\
\hline awareness of climate & $\begin{array}{c}0.088^{* * *} \\
(0.017)\end{array}$ & $\begin{array}{l}-0.001 \\
(0.023)\end{array}$ & $\begin{array}{c}0.008 \\
(0.017)\end{array}$ \\
\hline climate change denial & $\begin{array}{c}-0.072 * \\
(0.029)\end{array}$ & $\begin{array}{l}-0.012 \\
(0.022)\end{array}$ & $\begin{array}{l}-0.002 \\
(0.026)\end{array}$ \\
\hline declaration to pay & $\begin{array}{c}0.598^{* * *} \\
(0.032)\end{array}$ & $\begin{array}{c}-0.434^{* *} \\
(0.132)\end{array}$ & $\begin{array}{l}0.230 * \\
(0.096)\end{array}$ \\
\hline female & $\begin{array}{c}0 \\
(0.082)\end{array}$ & $\begin{array}{l}0.204 * \\
(0.101)\end{array}$ & $\begin{array}{c}-0.395^{* * *} \\
(0.119)\end{array}$ \\
\hline age & $\begin{array}{c}-0.005+ \\
(0.003)\end{array}$ & $\begin{array}{l}0.015 * * \\
(0.005)\end{array}$ & $\begin{array}{c}-0.022 * * * \\
(0.002)\end{array}$ \\
\hline high education & $\begin{array}{c}0.302 \text { ** } \\
(0.108)\end{array}$ & $\begin{array}{c}-0.092 \\
(0.06)\end{array}$ & $\begin{array}{l}-0.014 \\
(0.091)\end{array}$ \\
\hline big city & $\begin{array}{c}0.139 \\
(0.095)\end{array}$ & $\begin{array}{l}-0.096 \\
(0.166) \\
\end{array}$ & $\begin{array}{c}0.135 \\
(0.116)\end{array}$ \\
\hline village & $\begin{array}{l}-0.101 \\
(0.068)\end{array}$ & $\begin{array}{c}0.091 \\
(0.137)\end{array}$ & $\begin{array}{c}0.025 \\
(0.075)\end{array}$ \\
\hline household size & $\begin{array}{c}0.103^{* * *} \\
(0.018)\end{array}$ & $\begin{array}{c}0.019 \\
(0.044) \\
\end{array}$ & $\begin{array}{c}0.070 * * \\
(0.026)\end{array}$ \\
\hline house & $\begin{array}{c}0.045 \\
(0.072) \\
\end{array}$ & $\begin{array}{l}-0.104 \\
(0.079) \\
\end{array}$ & $\begin{array}{l}-0.086 \\
(0.069)\end{array}$ \\
\hline own home & $\begin{array}{l}-0.115 \\
(0.131) \\
\end{array}$ & $\begin{array}{c}-0.278 * \\
(0.113)\end{array}$ & $\begin{array}{l}0.109 * * \\
(0.035)\end{array}$ \\
\hline rich & $\begin{array}{l}-0.118 \\
(0.072)\end{array}$ & $\begin{array}{c}-0.1 \\
(0.153)\end{array}$ & $\begin{array}{c}0.333^{* * *} \\
(0.026)\end{array}$ \\
\hline poor & $\begin{array}{c}-0.356 \text { ** } \\
(0.121)\end{array}$ & $\begin{array}{c}0.15 \\
(0.147)\end{array}$ & $\begin{array}{c}-0.185+ \\
(0.103)\end{array}$ \\
\hline constant & $\begin{array}{l}-0.479 \\
(0.423)\end{array}$ & $\begin{array}{c}-0.986^{*} \\
(0.496)\end{array}$ & $\begin{array}{c}-1.090^{* *} \\
(0.386)\end{array}$ \\
\hline observations & 2464 & 2464 & 2464 \\
\hline
\end{tabular}


Table 3. Results from the GSEM, part III. Authors' own analysis, based on data obtained during an online questionnaire completed in four countries. $+p<0.10,{ }^{*} p<0.05,{ }^{* *} p<0.01,{ }^{* * *} p<0.001$, the standard errors clustered in countries are reported in parentheses.

\begin{tabular}{|c|c|c|c|c|c|}
\hline & $\begin{array}{c}\text { Social } \\
\text { Environment }\end{array}$ & $\begin{array}{c}\text { Friends Save by } \\
\text { Behavior }\end{array}$ & $\begin{array}{l}\text { Friends Major } \\
\text { Investors }\end{array}$ & $\begin{array}{l}\text { Friends Minor } \\
\text { Investors }\end{array}$ & $\begin{array}{c}\text { Comfort } \\
\text { Attachment }\end{array}$ \\
\hline modern val & $\begin{array}{l}0.102 * \\
(0.048)\end{array}$ & $\begin{array}{l}-0.023 \\
(0.041) \\
\end{array}$ & $\begin{array}{l}0.079 \\
(0.07) \\
\end{array}$ & $\begin{array}{c}0.087+ \\
(0.05)\end{array}$ & $\begin{array}{c}0.356^{* * *} \\
(0.081)\end{array}$ \\
\hline traditional val & $\begin{array}{l}0.155+ \\
(0.083)\end{array}$ & $\begin{array}{c}0.154 \\
(0.114)\end{array}$ & $\begin{array}{l}0.057+ \\
(0.032)\end{array}$ & $\begin{array}{l}0.170+ \\
(0.101)\end{array}$ & $\begin{array}{c}0.059 \\
(0.161)\end{array}$ \\
\hline $\begin{array}{l}\text { awareness of } \\
\text { climate }\end{array}$ & $\begin{array}{l}0.039 * * * \\
(0.011)\end{array}$ & $\begin{array}{c}0.037 \\
(0.026)\end{array}$ & $\begin{array}{c}-0.025+ \\
(0.013)\end{array}$ & $\begin{array}{l}0.031+ \\
(0.017)\end{array}$ & $\begin{array}{c}0.053+ \\
(0.03)\end{array}$ \\
\hline $\begin{array}{c}\text { climate change } \\
\text { denial }\end{array}$ & $\begin{array}{c}-0.069 * * * \\
(0.017)\end{array}$ & $\begin{array}{c}-0.053 * * * \\
(0.012)\end{array}$ & $\begin{array}{c}0.058^{* * *} \\
(0.01)\end{array}$ & $\begin{array}{c}-0.042^{* *} \\
(0.014)\end{array}$ & $\begin{array}{l}0.026+ \\
(0.016)\end{array}$ \\
\hline declaration to pay & $\begin{array}{c}0.486 \text { *** } \\
(0.078)\end{array}$ & $\begin{array}{l}0.289 * \\
(0.144)\end{array}$ & $\begin{array}{l}0.524^{* * *} \\
(0.091)\end{array}$ & $\begin{array}{l}0.183+ \\
(0.102)\end{array}$ & $\begin{array}{l}-0.076 \\
(0.083)\end{array}$ \\
\hline female & $\begin{array}{l}-0.016 \\
(0.04)\end{array}$ & $\begin{array}{c}0.230 * * * \\
(0.066)\end{array}$ & $\begin{array}{l}-0.139^{* * *} \\
(0.034)\end{array}$ & $\begin{array}{l}-0.029 \\
(0.057)\end{array}$ & $\begin{array}{l}0.358^{*} \\
(0.172)\end{array}$ \\
\hline age & $\begin{array}{l}0.004 * \\
(0.002)\end{array}$ & $\begin{array}{l}-0.008^{* * *} \\
(0.002)\end{array}$ & $\begin{array}{l}-0.012 * \\
(0.005)\end{array}$ & $\begin{array}{l}0.008 * * \\
(0.003)\end{array}$ & $\begin{array}{c}0.030 * * * \\
(0.003)\end{array}$ \\
\hline high education & $\begin{array}{c}0.11 \\
(0.083)\end{array}$ & $\begin{array}{c}0.08 \\
(0.066)\end{array}$ & $\begin{array}{l}0.117 * \\
(0.047)\end{array}$ & $\begin{array}{l}-0.019 \\
(0.082)\end{array}$ & $\begin{array}{l}0.414^{* * *} \\
(0.118)\end{array}$ \\
\hline big city & $\begin{array}{l}0.310^{*} \\
(0.131)\end{array}$ & $\begin{array}{c}0.204^{* *} \\
(0.073)\end{array}$ & $\begin{array}{c}0.097^{* *} \\
(0.035)\end{array}$ & $\begin{array}{l}0.238 * \\
(0.12)\end{array}$ & $\begin{array}{c}0.146 \\
(0.119)\end{array}$ \\
\hline village & $\begin{array}{l}-0.192 * \\
(0.083)\end{array}$ & $\begin{array}{l}-0.089 \\
(0.121)\end{array}$ & $\begin{array}{c}-0.138 \text { ** } \\
(0.052)\end{array}$ & $\begin{array}{c}-0.196 \text { * } \\
(0.093)\end{array}$ & $\begin{array}{c}0.143 \\
(0.095)\end{array}$ \\
\hline household size & $\begin{array}{c}0.154^{* * *} \\
(0.044)\end{array}$ & $\begin{array}{c}0.152 * * * \\
(0.012)\end{array}$ & $\begin{array}{l}0.082 * \\
(0.038)\end{array}$ & $\begin{array}{c}0.144^{* * *} \\
(0.034)\end{array}$ & $\begin{array}{c}0.249 * * * \\
(0.045)\end{array}$ \\
\hline house & $\begin{array}{c}0.114 \\
(0.073)\end{array}$ & $\begin{array}{l}-0.063 \\
(0.045)\end{array}$ & $\begin{array}{c}0.413^{* * *} \\
(0.086)\end{array}$ & $\begin{array}{l}-0.082 \\
(0.056)\end{array}$ & $\begin{array}{c}-0.276 \\
(0.177)\end{array}$ \\
\hline own home & $\begin{array}{c}0.03 \\
(0.054)\end{array}$ & $\begin{array}{l}-0.059 \\
(0.069)\end{array}$ & $\begin{array}{c}0.154+ \\
(0.083)\end{array}$ & $\begin{array}{c}0.011 \\
(0.125)\end{array}$ & $\begin{array}{c}0.190^{* * *} \\
(0.049)\end{array}$ \\
\hline rich & $\begin{array}{c}0.04 \\
(0.057) \\
\end{array}$ & $\begin{array}{c}-0.162 \text { ** } \\
(0.061)\end{array}$ & $\begin{array}{c}0.028 \\
(0.096)\end{array}$ & $\begin{array}{l}-0.023 \\
(0.017)\end{array}$ & $\begin{array}{l}-0.091 \\
(0.092)\end{array}$ \\
\hline poor & $\begin{array}{l}-0.099 \\
(0.137)\end{array}$ & $\begin{array}{c}-0.164 \\
(0.119)\end{array}$ & $\begin{array}{l}-0.224 \\
(0.219)\end{array}$ & $\begin{array}{c}-0.167 \text { * } \\
(0.081)\end{array}$ & $\begin{array}{c}-0.183+ \\
(0.101)\end{array}$ \\
\hline constant & $\begin{array}{c}0.647+ \\
(0.339)\end{array}$ & $\begin{array}{l}-0.524 \\
(0.356)\end{array}$ & $\begin{array}{c}-1.789^{* * *} \\
(0.201)\end{array}$ & $\begin{array}{c}-2.271^{* * *} \\
(0.357)\end{array}$ & $\begin{array}{c}0.694 \\
(0.609)\end{array}$ \\
\hline observations & 2464 & 2464 & 2464 & 2464 & 2464 \\
\hline
\end{tabular}

Another influential factor in our study is the social environment: talking about energy and observing energy-saving behaviors is significantly connected to individual choices and attitudes, and this was confirmed in all indicators of energy-saving behaviors and intentions we analyzed. Interestingly, respondents tended to take actions similar to their friends and family, and showed intentions to follow particular types of actions that were popular in their social networks. This is in accordance with the literature, which recognizes the importance of social context $[47,48,57,58]$. Attachment to comfort is unconnected with investments in energy saving solutions, but is linked to intentions to save by changing behavior, plans to purchase ecological cars, and interest in smart grid concepts. Attachment to comfort, in contrast to some predictions in the literature [53], does not, therefore, seem to contradict energy-saving behaviors and actions; on the contrary, it correlates positively 
with intentions to undertake electrical energy-saving actions. This supports the claim that economizing on electricity consumption can be performed with a view to increasing an individual's consumption of other goods [32,38].

Table 2 presents the results of the factors explaining ecological, financial, and technological motivations; Table 3 presents the determinants of energy-related participation in social networks, and personal attachment to comfort. These relate to the predictions of relationships formulated in Hypotheses 2-5, and serve to broaden the reader's understanding of the background of the analyzed energy-saving behaviors, intentions, and motivations.

Saving energy for environmental reasons is more common among respondents who talk about it in their social networks, have friends who save energy through behavioral changes and minor investments, are aware of the climate crisis, and hold traditional values. Such individuals are aware of the threat of climate change, and are ready to pay for its mitigation. They are well-educated, middle-income individuals who live in larger households. Attachment to comfort is insignificant in explaining ecological reasons, which indicates that it does not go hand-in-hand with saving energy due to pro-environmental concerns. This corresponds with research indicating that attitudes based on hedonistic values can hinder the adoption of energy-saving behaviors [53].

Financial considerations primarily influence those with traditional values, who are older and are unwilling to pay to prevent the climate crisis. These individuals have friends who save energy through changes in behavior, but decline to make major investments in pro-environmental installations. These respondents typically do not own their homes, and are more frequently female than male. They are primarily motivated by financial gain and are frugal and therefore less likely to make energy-saving investments. This group reacts principally to monetary feedback, and views arguments regarding potential environmental gains to be less valid than others [53].

As we found out, new technologies serve as a motivator for high earners, who are attached to comfort and own their homes. These are more often men, younger than average, often talk about energy conservation, and adhere to modern values. They can afford major investments in installations, are attracted by new technological solutions for energy saving, and most probably treat them as a way of enhancing their social status and projecting a modern image of themselves [56]. In such cases, there is no sign of higher-thanaverage concern about climate change, but such individuals are ready to make financial contributions to its mitigation. This does not mean, however, that this group is likely to reduce its general consumption in the name of protecting the environment; they value comfort and a high standard of living.

Participation in social networks which engage in energy-saving discussions and give access to observations of energy-saving behaviors is connected with awareness and acceptance of climate change challenges, as well as readiness to pay for its mitigation. More social exposure in this context is experienced by older respondents, who live in large cities and not villages, have larger households, and are driven by modern values. These characteristics differ when we investigate different types of energy-saving actions taken by family and friends; this is most probably related to the existence of different residential districts and social circles, which can have a specific influence on individual reasons to save energy. Attachment to comfort is specific for respondents who are older, female, better educated, live in larger households, own their homes, and live by modern values.

We discovered that the pro-environmental energy use behaviors and intentions we analyzed are primarily determined by ecological reasons and openness to new technologies. The second correlates both with high attachment to consumption and high financial status. This means that for at least some people, who can afford investments in energy-saving installations, observed and planned pro-environmental behaviors in the use of electricity in households are not connected with a total consumption reduction and correspond with an increase in comfort and standards of living. A crucial role is played by social networks and the discussion of energy saving with other people. As it can be deduced from our results, this enforces not only the analyzed behaviors and intentions, but also their underlying 
motivations: ecological reasons and openness to new technologies. There is ample evidence of homophily among respondents towards their social surroundings in the types of energysaving actions they undertake. When the intentions of respondents follow the actions observed within social networks, we might assert that it is caused by social influence [70]. If actual actions correspond with standard solutions in the social surrounding, however, this resemblance might be due to selection-the tendency to create friendships with likeminded individuals - and not to social influence [83]. This is impossible to distinguish without access to longitudinal data-the absence of which is a potential limitation of our survey.

Our findings support that climate awareness strengthens ecological motivations for electrical energy conservation. Modern values positively correlate with eagerness for technology, but stand in opposition to environmental considerations; while traditional values precede both ecological (love of nature) and financial (frugality) ones. In the case of our respondents, higher age is a barrier to the adoption of new technologies, and experience of higher education enhances ecological motivation. Being wealthy precedes higher interest in technologies, and being poor spawns a lower tendency to be directed by ecological concerns. Interestingly, as we demonstrated, being frugal and driven by financial considerations correlates more closely with the possession of traditional values than with the material status.

\section{Discussion}

We discovered that the most important reasons behind the actions and intentions to reduce the consumption of electricity at homes are ecological concerns and interest in new technologies. Interestingly, attachment to comfort is congruous with readiness to engage in electrical energy-saving behaviors and interest in smart-grid solutions, which suggests that individuals economize on electrical energy with the intention of improving their standard of living, and not reducing their overall consumption, nor accepting the potential inconvenience of undertaking pro-environmental measures.

Measures to conserve electrical energy and install renewable energy equipment in residential homes are not driven solely by ecological concerns. Individuals can fail to reduce the carbon footprint if they reduce electrical energy expenditure in order to redirect those savings to the consumption of other goods or if they increase the electricity use efficiency without decreasing the overall electrical energy consumption. Increasing the popularity of electrical energy-saving solutions while maintaining the well-trodden consumption-growth path might prove inadequate in the face of environmental threats [20] and the potential reduction of affordable fossil fuels [84].

A key role is played by social networks. Discussions on energy conservation and the observation of energy-saving actions taken by those in an individual's social surroundings are linked to energy saving behaviors and intentions. Specific actions taken by friends also demonstrate a clear correspondence with the responses of the survey participants. The actions of the subjects are similar: they change their behavior when their friends save energy in the same way; they decide on major or minor investments when their friends have opted for the same solutions. This has important implications for policies intended to foster energy-saving attitudes and behaviors: they should be addressed towards whole communities, rather than individual energy users.

In conclusion, we can observe that ecological motivation is a significant reason for both actual and planned electrical energy-saving actions, which indicates that climate and environmental awareness and the high value of nature is already present in the decisions of electricity users. Contrarily, ecological motivation occurs alongside others, such as financial reasons, new technologies, social environment, or comfort concerns.

This opens a variety of scenarios for the future. Meeting GHG emission reduction targets and the associated reduction in energy consumption will require a significant redesign not only of the energy system, but also of individual lifestyles. Some of the actions required for a successful transformation are relatively painless, in cases in which meeting 
the requirements to reduce or shift energy consumption simultaneously brings benefits in other areas, such as reduced expenditure, enhancement of comfort, or satisfaction from using modern technologies. It should be remembered, however, that the actions being taken at present are far from sufficient to meet decarbonization goals. Current efforts to reduce electrical energy consumption and increase the flexibility of demand are being undertaken in the reality of ever-growing global demand for energy and rising GHG emissions [85]. Decarbonizing the energy sector will require more definitive actions to reverse this trend [79].

It is difficult to predict at present how such solutions will be evaluated in the future. On the one hand, we can assume that future energy reduction solutions will have similar benefits to the current ones-that they will enable monetary savings, will be modern, and will reduce GHG emissions; on the other, reversing the current trend of ever-growing energy demand will require much more radical action than is currently being taken. Steps to reduce energy consumption might become a necessity in order to enable actual reductions in global GHG emissions and extend the time in which we have access to relatively affordable fossil fuels, which allows us to transform the economy to use new energy sources [4]. Decisive action to reduce energy consumption might serve to alter public opinion on such measures. In view of the results of this study, we see a risk that the current ecological motivations do not prove to be the launch pad for a deeper change towards pro-environmental attitudes, but that they are perceived merely as another of the many benefits provided by current consumer goods. It may be that when it becomes necessary to seriously decrease consumption of fossil fuels, social acceptance for such actions will be lower than current declarations indicate.

Individuals have different motivations for saving electrical energy, and only some are driven by unconditional care for the environment; others value saving money more, or living in comfort, or enhancing their social status. Although all of those reasons currently serve to increase the incidence of pro-environmental measures and interest in such solutions, they might not work when reductions in consumption and acceptance of inconvenience due to the needs of electrical energy-demand flexibility is required. One solution is to deepen public awareness of climate change, and develop educational policies intended to foster pro-ecological and energy saving attitudes, with consideration for the role of social networks in the alteration of social norms and individual perceptions. This is a requisite for the social support of potentially restrictive international agreements designed to ensure reductions in energy dependence. Another potential solution involves subsidising the development of new technologies that enable further economic growth and increases in standards of living without threatening non-renewable resources, in the hope that they will be invented in time to prevent the most critical consequences of global climate crisis and the potential shortage of available fossil fuels.

Author Contributions: Conceptualization, Z.B., B.Ł.-G. and J.K.; methodology, Z.B. and B.Ł.-G.; validation, Z.B. and B.Ł.-G.; formal analysis, B.Ł.-G.; investigation, Z.B., B.Ł.-G. and J.K.; resources, Z.B., J.K. and C.B.; data curation, Z.B., B.Ł.-G. and J.K.; writing-original draft preparation, Z.B., B.Ł.-G. and J.K.; writing-review and editing, Z.B. and B.Ł.-G; visualization, Z.B. and B.Ł.-G.; supervision, C.B.; project administration, Z.B., J.K. and C.B.; funding acquisition, Z.B., J.K. and C.B. All authors have read and agreed to the published version of the manuscript.

Funding: This research is part of a project that has received funding from the European Union's Horizon 2020 research and innovation programme under grant agreement No.864283.

Informed Consent Statement: Informed consent was obtained from all subjects involved in the study.

Data Availability Statement: The data presented in this study are openly available in Mendeley Data at doi:10.17632/g3phyn9kms.1.

Acknowledgments: We would like to thank National Information Processing Institute, Warsaw, Poland for administrative support and language edition. 
Conflicts of Interest: The authors declare no conflict of interest. The funders had no role in the design of the study; in the collection, analyses, or interpretation of data; in the writing of the manuscript, or in the decision to publish the results.

\section{References}

1. Masson-Delmotte, V.; Zhai, P.; Pirani, A.; Connors, S.L.; Péan, C.; Berger, S.; Caud, N.; Chen, Y.; Goldfarb, L.; Gomis, M.I.; et al. IPCC Sixth Assessment Report (AR6), WG1; Cambridge University Press: Cambridge, UK, 2021.

2. Höök, M.; Tang, X. Depletion of fossil fuels and anthropogenic climate change-A review. Energy Policy 2013, 52, 797-809. [CrossRef]

3. Hansen, J.E. Environment and development challenges. In The Oxford Handbook of the Macroeconomics of Global Warming; Semmler, L.B.A., Ed.; Oxford University Press: Oxford, UK, 2015; ISBN 9780199856978.

4. Delannoy, L.; Longaretti, P.-Y.; Murphy, D.J.; Prados, E. Peak oil and the low-carbon energy transition: A net-energy perspective. Appl. Energy 2021, 304, 117843. [CrossRef]

5. Sugiyama, M. Climate change mitigation and electrification. Energy Policy 2012, 44, 464-468. [CrossRef]

6. Allcott, H.; Mullainathan, S. Energy. behavior and energy policy. Science 2010, 327, 1204-1205. [CrossRef]

7. Steg, L.; Shwom, R.; Dietz, T. What drives energy consumers?: Engaging people in a sustainable energy transition. IEEE Power Energy Mag. 2018, 16, 20-28. [CrossRef]

8. Stern, P.C. Individual and household interactions with energy systems: Toward integrated understanding. Energy Res. Soc. Sci. 2014, 1, 41-48. [CrossRef]

9. Monti, A.; Pesch, D.; Ellis, K.; Mancarella, P. Energy Positive Neighborhoods and Smart Energy Districts: Methods, Tools, and Experiences from the Field, 1st ed.; Monti, A., Pesch, D., Ellis, K., Mancarella, P., Eds.; Academic Press: Cambridge, MA, USA, 2016; 227p, ISBN 9780128099513.

10. Jones, R.V.; Fuertes, A.; Lomas, K.J. The socio-economic, dwelling and appliance related factors affecting electricity consumption in domestic buildings. Renew. Sustain. Energy Rev. 2015, 43, 901-917. [CrossRef]

11. Gottwalt, S.; Gärttner, J.; Schmeck, H.; Weinhardt, C. Modeling and valuation of residential demand flexibility for renewable energy integration. IEEE Trans. Smart Grid 2017, 8, 2565-2574. [CrossRef]

12. Parrish, B.; Heptonstall, P.; Gross, R.; Sovacool, B.K. A systematic review of motivations, enablers and barriers for consumer engagement with residential demand response. Energy Policy 2020, 138, 111221. [CrossRef]

13. Pandey, D.; Agrawal, M.; Pandey, J.S. Carbon footprint: Current methods of estimation. Environ. Monit. Assess. 2011, 178, 135-160. [CrossRef]

14. van den Broek, K.L.; Walker, I. Exploring the perceptions of drivers of energy behaviour. Energy Policy 2019, 129, 1297-1305. [CrossRef]

15. Gołębiowska, B.; Bartczak, A.; Czajkowski, M. Energy demand management and social norms. Energies 2020, 13, 3779. [CrossRef]

16. Poortinga, W.; Fisher, S.; Bohm, G.; Steg, L.; Whitmarsh, L.; Ogunbode, C. European Attitudes to Climate Change and Energy: Topline Results from Round 8 of the European Social Survey; European Social Survey ERIC City, University of London Northampton Square: London, UK, 2018.

17. Bohdanowicz, Z. Different countries, common support for climate change mitigation: The case of Germany and Poland. Climate 2021, 9, 27. [CrossRef]

18. Abrahamse, W.; Steg, L. How do socio-demographic and psychological factors relate to households' direct and indirect energy use and savings? J. Econ. Psychol. 2009, 30,711-720. [CrossRef]

19. Shove, E. What is wrong with energy efficiency? Build. Res. Inf. 2018, 46, 779-789. [CrossRef]

20. Moriarty, P.; Honnery, D. The risk of catastrophic climate change: Future energy implications. Futures 2021, 128, 102728. [CrossRef]

21. Brookes, L. The greenhouse effect: The fallacies in the energy efficiency solution. Energy Policy 1990, 18, 199-201. [CrossRef]

22. Rajbhandari, A.; Zhang, F. Does energy efficiency promote economic growth? Evidence from a multicountry and multisectoral panel dataset. Energy Econ. 2018, 69, 128-139. [CrossRef]

23. Cantore, N.; Calì, M.; Velde, D.W.T. Does energy efficiency improve technological change and economic growth in developing countries? Energy Policy 2016, 92, 279-285. [CrossRef]

24. Bataille, C.; Melton, N. Energy efficiency and economic growth: A retrospective CGE analysis for Canada from 2002 to 2012. Energy Econ. 2017, 64, 118-130. [CrossRef]

25. Santos, J.; Borges, A.S.; Domingos, T. Exploring the links between total factor productivity and energy efficiency: Portugal, 1960-2014. Energy Econ. 2021, 101, 105407. [CrossRef]

26. Fouquet, R.; Pearson, P.J.G. Seven centuries of energy services: The price and use of light in the United Kingdom (1300-2000). Energy J. 2006, 27, 139-177. [CrossRef]

27. Ajanovic, A.; Schipper, L.; Haas, R. The impact of more efficient but larger new passenger cars on energy consumption in EU-15 countries. Energy 2012, 48, 346-355. [CrossRef]

28. Lutsey, N.; Sperling, D. Energy efficiency, fuel economy, and policy implications. Transp. Res. Rec. 2005, 1941, 8-17. [CrossRef]

29. Munyon, V.V.; Bowen, W.M.; Holcombe, J. Vehicle fuel economy and vehicle miles traveled: An empirical investigation of Jevon's Paradox. Energy Res. Soc. Sci. 2018, 38, 19-27. [CrossRef] 
30. Yoo, S.; Cho, A.; Salman, F.; Yoshida, Y. Green paradox: Factors affecting travel distances and fuel usages, evidence from Japanese survey. J. Clean. Prod. 2020, 273, 122280. [CrossRef]

31. Wilson, A.; Boehland, J. Small is beautiful U.S. house size, resource use, and the environment. J. Ind. Ecol. 2005, 9, 277-287. [CrossRef]

32. Alcott, B. Jevons' Paradox. Ecol. Econ. 2005, 54, 9-21. [CrossRef]

33. Sorrell, S. Jevons' Paradox revisited: The Evidence for backfire from improved energy efficiency. Energy Policy 2009, 37, 1456-1469. [CrossRef]

34. Binswanger, M. Technological progress and sustainable development: What about the rebound effect? Ecol. Econ. 2001, 36, 119-132. [CrossRef]

35. Brookes, L. Energy Efficiency fallacies revisited. Energy Policy 2000, 28, 355-366. [CrossRef]

36. Schipper, L.; Grubb, M. On the rebound? Feedback between energy intensities and energy uses in IEA countries. Energy Policy 2000, 28, 367-388. [CrossRef]

37. Greening, L.A.; Greene, D.L.; Difiglio, C. Energy efficiency and consumption—the rebound effect-A survey. Energy Policy 2000, 28, 389-401. [CrossRef]

38. Herring, H. Energy efficiency-A critical view. Energy 2006, 31, 10-20. [CrossRef]

39. Sorrell, S.; Dimitropoulos, J.; Sommerville, M. Empirical estimates of the direct rebound effect: A review. Energy Policy 2009, 37, 1356-1371. [CrossRef]

40. Brockway, P.E.; Sorrell, S.; Semieniuk, G.; Heun, M.K.; Court, V. Energy efficiency and economy-wide rebound effects: A review of the evidence and its implications. Renew. Sustain. Energy Rev. 2021, 141, 110781. [CrossRef]

41. Wei, T.; Liu, Y. Estimation of global rebound effect caused by energy efficiency improvement. Energy Econ. 2017, 66, 27-34. [CrossRef]

42. Rees, W.E. The ecological crisis and self-delusion: Implications for the building sector. Build. Res. Inf. 2009, 37, 300-311. [CrossRef]

43. Torriti, J.; Santiago, I. Simultaneous activities in the household and residential electricity demand in Spain. Time Soc. 2019, 28, 175-199. [CrossRef]

44. Zerubavel, E. Hidden Rhythms: Schedules and Calendars in Social Life; University of Chicago Press: Chicago, IL, USA, 1981; ISBN 9780226981628.

45. Blue, S.; Shove, E.; Forman, P. Conceptualising flexibility: Challenging representations of time and society in the energy sector* Time Soc. 2020, 29, 923-944. [CrossRef]

46. Shakoor, A.; Davies, G.; Strbac, G. Roadmap for Flexibility Services to 2030. A Report to the Committee on Climate Change; Pöyry: London, UK, 2017.

47. Gadenne, D.; Sharma, B.; Kerr, D.V.; Smith, T. The influence of consumers' environmental beliefs and attitudes on energy saving behaviours. Energy Policy 2011, 39, 7684-7694. [CrossRef]

48. Wang, B.; Wang, X.; Guo, D.; Zhang, B.; Wang, Z. Analysis of factors influencing residents' habitual energy-saving behaviour based on NAM and TPB models: Egoism or altruism? Energy Policy 2018, 116, 68-77. [CrossRef]

49. Wittenberg, I.; Blöbaum, A.; Matthies, E. Environmental motivations for energy use in pv households: Proposal of a modified norm activation model for the specific context of PV households. J. Environ. Psychol. 2018, 55, 110-120. [CrossRef]

50. Hansla, A.; Gamble, A.; Juliusson, A.; Gärling, T. Psychological determinants of attitude towards and willingness to pay for green electricity. Energy Policy 2008, 36, 768-774. [CrossRef]

51. Steg, L. Values, norms, and intrinsic motivation to act proenvironmentally. Annu. Rev. Environ. Resour. 2016, 41, 277-292. [CrossRef]

52. Schwartz, D.; Bruine de Bruin, W.; Fischhoff, B.; Lave, L. Advertising energy saving programs: The potential environmental cost of emphasizing monetary savings. J. Exp. Psychol. Appl. 2015, 21, 158-166. [CrossRef]

53. Brandsma, J.S.; Blasch, J.E. One for all?-The impact of different types of energy feedback and goal setting on individuals' motivation to conserve electricity. Energy Policy 2019, 135, 110992. [CrossRef]

54. Qiu, Y.; Colson, G.; Grebitus, C. Risk preferences and purchase of energy-efficient technologies in the residential sector. Ecol. Econ. 2014, 107, 216-229. [CrossRef]

55. Wilson, C.; Hargreaves, T.; Hauxwell-baldwin, R. Benefits and risks of smart home technologies. Energy Policy 2017, 103, 72-83. [CrossRef]

56. Frank, B.; Enkawa, T.; Schvaneveldt, S.J.; Herbas Torrico, B. Antecedents and consequences of innate willingness to pay for innovations: Understanding motivations and consumer preferences of prospective early adopters. Technol. Forecast. Soc. Chang. 2015, 99, 252-266. [CrossRef]

57. Rogers, E.M. Diffusion of Innovations; Simon and Schuster: New York, NY, USA, 2010.

58. Bollinger, B.; Gillingham, K. Peer effects in the diffusion of solar photovoltaic panels. Mark. Sci. 2012, 31, 900-912. [CrossRef]

59. Perri, C.; Giglio, C.; Corvello, V. Smart users for smart technologies: Investigating the intention to adopt smart energy consumption behaviors. Technol. Forecast. Soc. Chang. 2020, 155, 119991. [CrossRef]

60. Wallis, H.; Klöckner, C. The transmission of energy-saving behaviors in the family: A multilevel approach to the assessment of aggregated and single energy-saving actions of parents and adolescents. Environ. Behav. 2020, 52, 275-304. [CrossRef]

61. Wolske, K.S.; Gillingham, K.T.; Schultz, P.W. Peer influence on household energy behaviours. Nat. Energy 2020, 5, $202-212$. [CrossRef] 
62. Jain, R.K.; Gulbinas, R.; Taylor, J.E.; Culligan, P.J. Can social influence drive energy savings? detecting the impact of social influence on the energy consumption behavior of networked users exposed to normative Eco-feedback. Energy Build. 2013, 66, 119-127. [CrossRef]

63. Delmas, M.A.; Fischlein, M.; Asensio, O.I. Information strategies and energy conservation behavior: A meta-analysis of experimental studies from 1975 to 2012. Energy Policy 2013, 61, 729-739. [CrossRef]

64. Steg, L.; Perlaviciute, G.; van der Werff, E.; Lurvink, J. The significance of hedonic values for environmentally relevant attitudes, preferences, and actions. Environ. Behav. 2014, 46, 163-192. [CrossRef]

65. van den Broek, K.L.; Walker, I.; Klöckner, C.A. Drivers of energy saving behaviour: The relative influence of intentional, normative, situational and habitual processes. Energy Policy 2019, 132, 811-819. [CrossRef]

66. Belaïd, F.; Joumni, H. Behavioral attitudes towards energy saving: Empirical evidence from france. Energy Policy 2020, $140,111406$. [CrossRef]

67. Gyamfi, S.; Krumdieck, S.; Urmee, T. Residential peak electricity demand response-Highlights of some behavioural issues. Renew. Sustain. Energy Rev. 2013, 25, 71-77. [CrossRef]

68. Taso, Y.-C.; Ho, C.-W.; Chen, R.-S. The impact of problem awareness and biospheric values on the intention to use a smart meter. Energy Policy 2020, 147, 111873. [CrossRef]

69. Madden, T.J.; Ellen, P.S.; Ajzen, I. A comparison of the theory of planned behavior and the theory of reasoned action. Pers. Soc. Psychol. Bull. 1992, 18, 3-9. [CrossRef]

70. Friedkin, N.E. A Structural Theory of Social Influence; Cambridge University Press: Cambridge, UK, 1998 ; ISBN 9780521454827.

71. Wilson, C.; Dowlatabadi, H. Models of decision making and residential energy use. Annu. Rev. Environ. Resour. 2007, 32, 169-203. [CrossRef]

72. Ajzen, I. The theory of planned behavior. Organ. Behav. Hum. Decis. Process. 1991, 50, 179-211. [CrossRef]

73. Schwartz, S.H. Normative influences on altruism. In Advances in Experimental Social Psychology; Elsevier: Amsterdam, The Netherlands, 1977; Volume 10, pp. 221-279.

74. Schwartz, S.; Howard, J. A normative decision making model of altruism. In Altruism and Helping Behavior: Social, Personality, and Developmental Perspectives; Rushton, P.J., Sorrentino, R.M., Eds.; Lawrence Erlbaum: Hillsdale, MI, USA, 1981 ; pp. $189-211$.

75. Homer, P.M.; Kahle, L.R. A structural equation test of the value-attitude-behavior hierarchy. J. Personal. Soc. Psychol. 1988, 54, 638-646. [CrossRef]

76. Stern, P.C.; Dietz, T.; Abel, T.D.; Guagnano, G.; Kalof, L. A value-belief-norm theory of support for social movements: The case of environmentalism. Hum. Ecol. Rev. 1999, 6, 81.

77. Abrahamse, W.; Steg, L. Factors related to household energy use and intention to reduce it: The role of psychological and socio-demographic variables. Hum. Ecol. Rev. 2011, 18, 30-40.

78. Fishbein, M.; Ajzen, A. Understanding Attitudes and Predicting Social Behaviour; Preventive-hall. Inc.: Englewood Cliffs, NJ, USA, 1980.

79. Rockström, J.; Gaffney, O.; Rogelj, J.; Meinshausen, M.; Nakicenovic, N.; Schellnhuber, H.J. A roadmap for rapid decarbonization. Science 2017, 355, 1269-1271. [CrossRef]

80. Molenaar, I.W. Nonparametric models for polytomous responses. In Handbook of Modern Item Response Theory; van der Linden, W.J., Hambleton, R.K., Eds.; Springer: New York, NY, USA, 1997; pp. 369-380. ISBN 9781475726916.

81. Sijtsma, K.; Molenaar, I.W. Introduction to Nonparametric Item Response Theory; SAGE Publications: Thousand Oaks, CA, USA, 2002; ISBN 9780761908128.

82. Rabe-Hesketh, S.; Skrondal, A.; Pickles, A. generalized multilevel structural equation modeling. Psychometrika 2004, 69, 167-190. [CrossRef]

83. Steglich, C.; Snijders, T.A.B.; Pearson, M. Dynamic networks and behavior: Separating selection from influence. Sociol. Methodol. 2010, 40, 329-393. [CrossRef]

84. Tverberg, G.E. Oil supply limits and the continuing financial crisis. Energy 2012, 37, 27-34. [CrossRef]

85. IEA Global Energy Review 2021. Available online: https://www.iea.org/reports/global-energy-review-2021 (accessed on 3 October 2021). 